Vol. XVII No. 4

\title{
Winter Bird Feeding
}

by Fred G. Bard, Sask. Museum of Natural History

At the S.N.H.S. annual meeting on October 17 the Moose Jaw Natural History Society distributed a list of birds and the kinds of food they would come to, with drawings of several types of winter feeding trays. Inquiries are coming in requesting information about feeding trays and foods, etc., and for this reason we would like to share your experiences by bringing them to the attention of other readers. Would you send to your Editor pictures of feeding trays that you have found successful, telling us of feed used.

Before the 30's we operated a feeding station back of the Normal School in which the Museum was housed. We brought in a few sreaves of various grains and put out a feed bed, scattering various kinds of grains for the birds. It was not long before we had a covey of Gray Partridge which fed daily and stayed during the cold winter. One thing that is often overlooked in feeding trays is the necessity of having grit or gravel handy at all times.

Almost every library can make books available on the various types of feeding trays. Many of these are quite elaborate; therefore some general suggestions regarding the most successful types are needed. Often students of birds can supply practical details lacking in tree books.

The feeding tray should be an elevated platform in order to give the birds some protection. It should have a canopy or cover (see figs. 1, 2) which prevents the snow from covering it. A hopper is desirable for a single filling could then serve probably a week or more at a time. I remember some years ago when Lloyd Carmichael, our former editor,

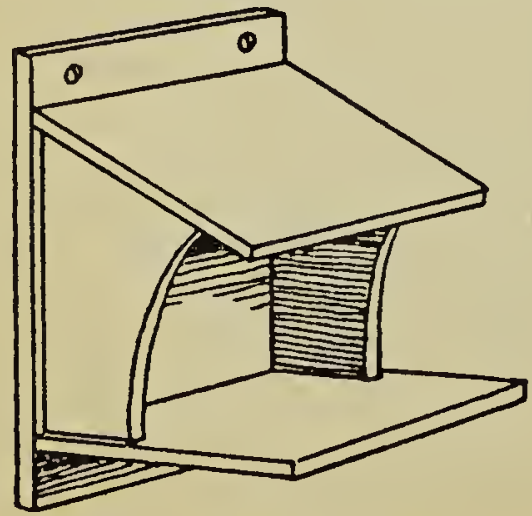

Fig. 1 Platform tray

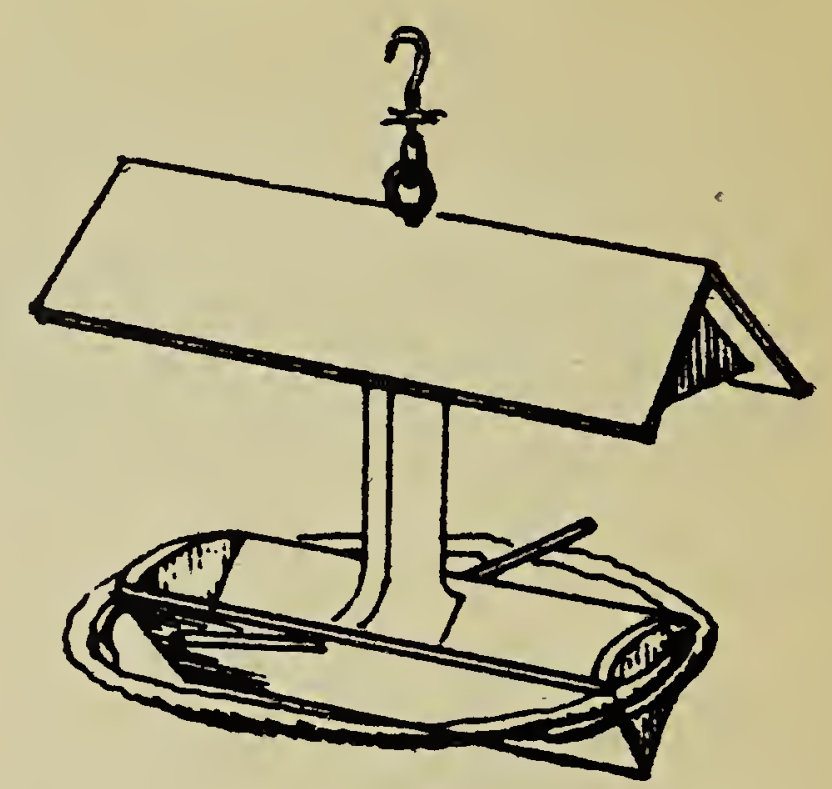

Fig. 2 Suspended trough with roof.-

gathered clusters of chokecherries and hung them out for the waxwings and other birds. It occurs to me that when these berries are plentiful we might gather a pailful and put them in a deep-freeze in small plastic bags to make them available to the birds during the winter months. Suet and similar types of food suit woodpeckers and chickadees very well; this can be fastened to the trunks of trees in protected areas. Our former treasurer, Elmer Fox, and Frank Brazier, former president of the Regina Natural History Society, rave had feeding stations for winter birds in the Legislative Grounds.

Be sure to study the types of birds you are likely to receive as visitors and provide the foods most acceptable to them. Last winter I had a feed bed for Gray Partridge on the Wascana Creek and these birds visited the feeding ground regularly, and by spring I had coaxed in four Sharp-tailed Grouse. This was unusual, for building development is going on all around. So, in addition to the regular visitors, one can expect a few very pleasant surprises with winter bird visitors.

\section{CAN YOU NAME THE BIRDS ON PAGE 143?}

Write to your Boys' and Girls' Editor, Miss Joyce Dew. 